\title{
Development of an Electronic Educational Kit with Android Application That Test Student Knowledge in Series and Parallel Resistor for Electrical Circuit (Res-Circuit Quiz Board)
}

\author{
Mohd Firdaus Mohd Ab Halim, Nur Azmeen Iezzati Idrus, Amar Faiz Zainal Abidin, Siti \\ Fatimah Sulaiman, Rozi Rifin
}

\begin{abstract}
One of the important subject inElectrical Engineering course is Electrical Circuit. The subject is known to be challenging as this is the first time student being expose to the Electrical Engineering subject. In order to address this, this paper is proposing an educational board, named Res-Circuit Quiz Board. The educational board is designed to test student's knowledge in series and parallel resistor connection for subject Electrical Circuit. An android based application is designedas interface for the quiz board to connect to through Bluetooth. The educational quiz board will give feedback to student based on the circuit connection done by the student. The effectiveness of the educational quiz board is measured using a survey done to the target audience. The result shows positive feedback from the respondents.
\end{abstract}

Index Terms: educational kit;learning tool;educational trainer;quiz board

\section{INTRODUCTION}

Res-Circuit Quiz Board is an educational kit that test students understanding in series and parallel resistor connection. This will be done by using application that required students to connect to it by using bluetooth to access to the kit. Students are required to answer the question given in the application by construct a circuit on the quiz board. Once the connection is completed, the application will check either the connection is correct or not.

The development of the project is purposely to gain the student interest in learning Electrical Circuit subject as an alternative approach to solving theoretical exercises in tutorial sessions, performing hands on tasks during laboratory sessions.According to [1], one of the most important barriers to the reform program was a shortage of learning activities that support hands-on learning and visible modelling to represent abstract concepts. This mean, one of

Revised Manuscript Received on July 05, 2019

Engineering Technology, Center for Robotics and Industrial Automation (CeRIA), Universiti Teknikal Malaysia Melaka, Melaka, Malaysia.

Nur Azmeen Iezzati Idrus, Faculty of Electrical Engineering Technology, Universiti Teknikal Malaysia Melaka, Melaka, Malaysia

Amar Faiz Zainal Abidin, Faculty of Electrical Engineering Technology, Universiti Teknikal Malaysia Melaka, Melaka, Malaysia.

Muhammad Salihin Saelal, Faculty of Electrical Engineering Technology, Universiti Teknikal Malaysia Melaka, Melaka, Malaysia.

Siti Fatimah Sulaiman, Faculty of Electronics and ComputerEngineering, Universiti Teknikal Malaysia Melaka, Melaka, Malaysia.

Rozi Rifin, Faculty of Electrical Engineering, Universiti Teknologi Mara Cawangan Johor, Kampus Pasir Gudang, Johor, Malaysia. the possible solutions isapplying construction kits to provide students with opportunities to actively engage and conduct experiments involving abstract theoretical concepts by using concrete products.

Past literatures shows several development of educational kit had been attempted in different areas of education: online learning [1-2], electrical engineering [3-11, 17], mathematics [12], chemical engineering [13, 15], and gaming [14, 16] None of the literatures have addressed the electrical circuit subject yet.

The objective of this project is to design a portable, cost effective, and durable educational quiz kit that tests the students understanding on series and parallel circuit connection that gives the attractive element that might be same with the electronic games.The Res-Circuit Quiz Board consists of six questions that need students to answer each of the questions from a simple to a complex circuit connection.

\section{RESEARCH METHODOLOGY}

\section{A.Project Layout}

Figure1 show the project layout that contain important components for this project. The main components are the female header, LEDs , and finally are theresistors; as the main components to make a complete circuit connection.

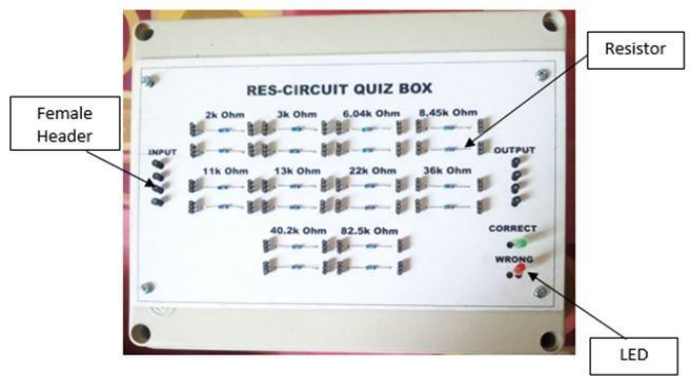

Fig. 1: Project layout

\section{B. Block Diagram}

Figure 2 show a block diagram representation of the project development. This project used Arduino Mega 2560 as microcontroller.Input for this project are included resistors as a component to make a circuit, female header as input connection between node and male to male jumper wire for node to node connection on Res-Circuit Quiz Board. Output for this project are green and red LED which used as indicator either the circuit connection is correct or not

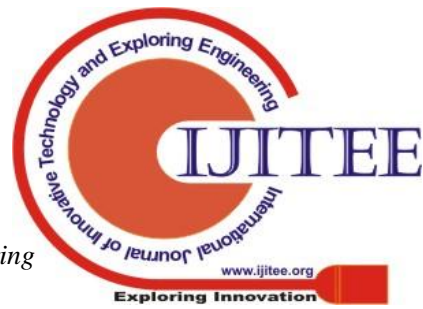



parallel resistor for electrical circuit (Res-Circuit Quiz Board)

Bluetooth module applied as the medium for data communication between mobile phone and the kit.

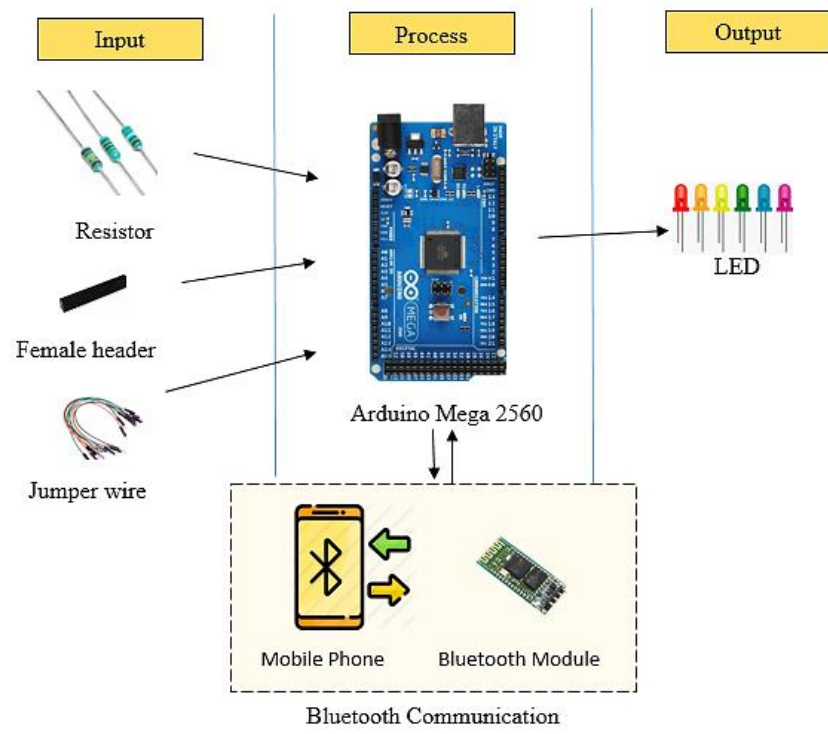

Fig. 2: Block diagram of the project

MIT App Inventor 2 was used to design theapplication as mobile interface. The application is connected to the kit by using bluetooth module as depicted in the Fig. 3 .

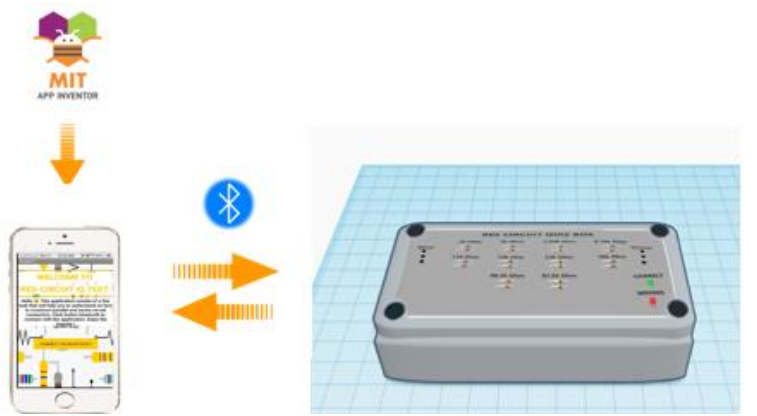

Fig. 3: The architecture of the project

\section{Flowchart}

This project required students to use Res-Circuit Quiz Application connected by using bluetooth to access to the kit. After succesfully connected to the application, there are three options (Easy, Medium, and Hard) provided to user which are include button for user to answer the question, button for user to give feedback and button to exit. There are six questionsdisplayed starting from a simple to complex circuit connection.The question will display when the question button is clicked. After answering all the questions, it will back to the option screen for user to choose either exit the application or giving the feedback. Figure 4 illustrated the process flow on how to execute this educational kit.

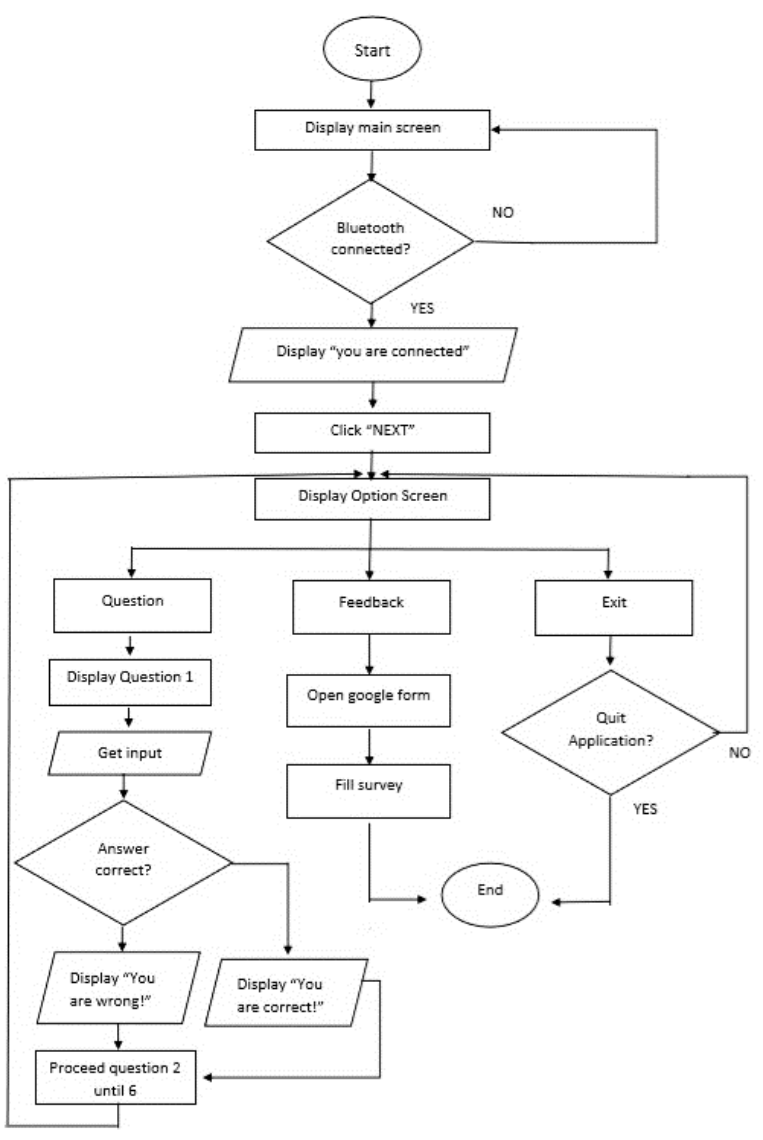

Fig. 4: Flowchart of the system

\section{Circuit Connection}

Before developing the project using the actual components, the circuit design and simulation were done using the Proteus Professional software as shown in the Figure 5. Circuit connections for the input pin header were connected to Arduino power source $(+5 \mathrm{~V})$. While the output pins header are connected to the fixed resistor of $7.15 \mathrm{k} \Omega$ which the fixed resistor is connected to the ground and between the resistor and pin output header is connected to analogue pin 8 . Red LED connected to the pins 23 and 25 while green LED connected to pins 27 and 29. As for Bluetooth module, it will be connected to the ground and power source $\left(V_{\mathrm{CC}}\right)$. Pin $\mathrm{Rx}$ will be connected to Tx of Arduino, while pin Tx of the Bluetooth module will be connected to pin $\mathrm{Rx}$ of Arduino.Table 1 summarizes the pin connections for the circuit

simulation.

Table 1: Pins connections

\begin{tabular}{|c|c|c|}
\hline Components & Component pins & Arduino pins \\
\hline \multirow{2}{*}{ Green LED } & Anode(+) & 27 \\
\cline { 2 - 3 } & Cathode(-) & 29 \\
\hline \multirow{2}{*}{ Red LED } & Anode(+) & 23 \\
\cline { 2 - 3 } & Cathode(-) & 25 \\
\hline \multirow{2}{*}{$\begin{array}{c}\text { Bluetooth } \\
\text { Module }\end{array}$} & Gnd & Gnd \\
\cline { 2 - 3 } & Vcc & $5 \mathrm{v}$ \\
\cline { 2 - 3 } & $\mathrm{Tx}$ & $\mathrm{Rx}$ \\
\cline { 2 - 3 } & $\mathrm{Rx}$ & $\mathrm{Tx}$ \\
\hline Input & Input header & $\mathrm{A} 8$ \\
\hline Output & Output Header & \\
\hline
\end{tabular}




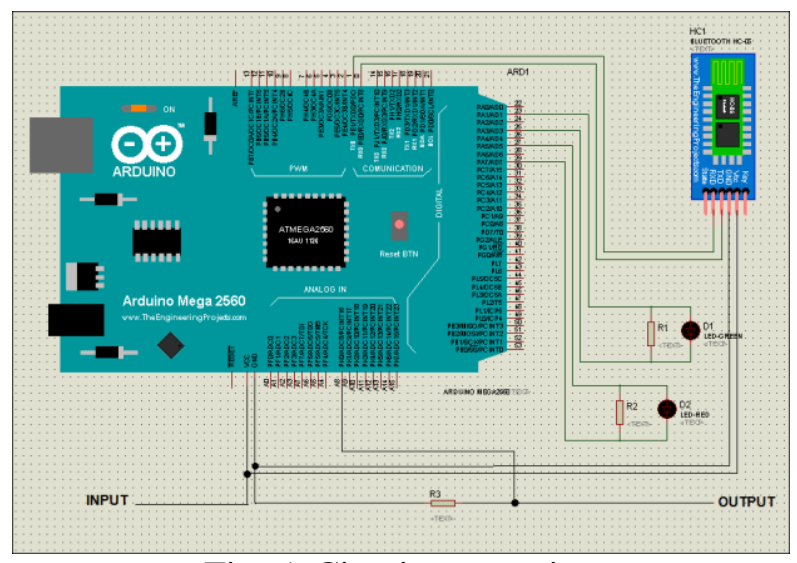

Fig. 5: Circuit connection

\section{RESULT AND DISCUSSION}

Comparison between the expected and actual results is carried out to observe the effectiveness of the kit. Table 2 show the result when user answer Question 1.

Table 2:Scenario based expected and actual results

\begin{tabular}{|c|c|c|c|}
\hline No & Scenario & $\begin{array}{c}\text { Expected } \\
\text { Result }\end{array}$ & Actual result \\
\hline 1 & $\begin{array}{l}\text { The } \\
\text { Res-Circuit } \\
\text { Quiz App is } \\
\text { opened and } \\
\text { required } \\
\text { user to } \\
\text { connect to } \\
\text { the } \\
\text { bluetooth. }\end{array}$ & $\begin{array}{l}\text { Main screen } \\
\text { will show and } \\
\text { there is button } \\
\text { bluetooth for } \\
\text { user to } \\
\text { connected to } \\
\text { the application. }\end{array}$ & 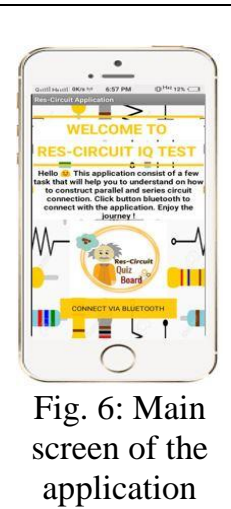 \\
\hline 2 & $\begin{array}{l}\text { After the } \\
\text { application } \\
\text { is connected } \\
\text { to the } \\
\text { bluetooth }\end{array}$ & $\begin{array}{l}\text { A new screen is } \\
\text { open that } \\
\text { consist a list of } \\
\text { option which is } \\
\text { button question } \\
\text { for user to star } \\
\text { the quiz, } \\
\text { button } \\
\text { feedback for } \\
\text { user to fill } \\
\text { survey and } \\
\text { feedback and } \\
\text { button exit. }\end{array}$ & 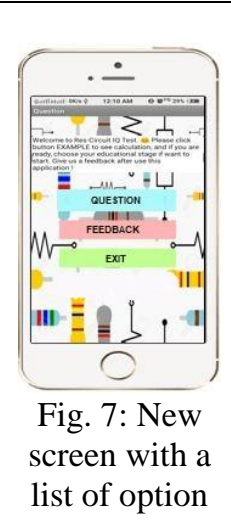 \\
\hline 3 & $\begin{array}{l}\text { User click } \\
\text { button } \\
\text { question and } \\
\text { answer the } \\
\text { Question 1 }\end{array}$ & $\begin{array}{l}\text { A new screen is } \\
\text { open and } \\
\text { display } \\
\text { Question } 1 . \\
\text { User construct } \\
\text { the circuit } \\
\text { according to } \\
\text { the question. }\end{array}$ & 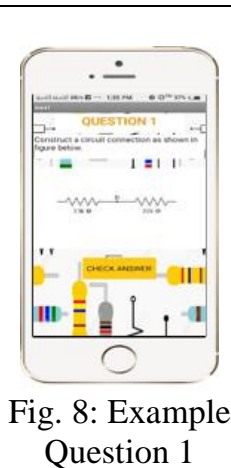 \\
\hline
\end{tabular}

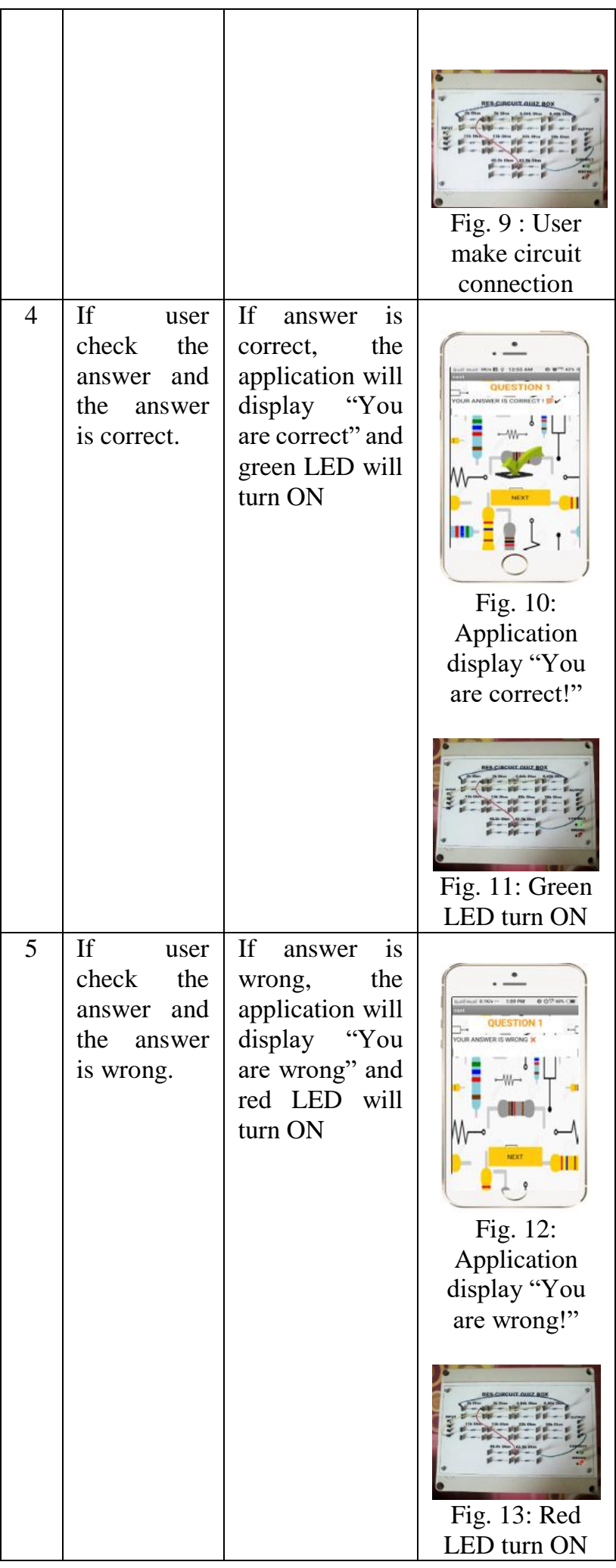

\section{B. Survey Analysis}

In order to achieve the objective of the project which is to gauge the effectiveness of the educational kit, asurvey has been carried out with 50 samples of feedback were collected. In order to ensure the quality of the survey, the questionnaire is taken from a proven literature [22]. The original literature consists of 18 questions where the first two questions are omitted for this survey.All questions are using 5-scale Linkert Scale.

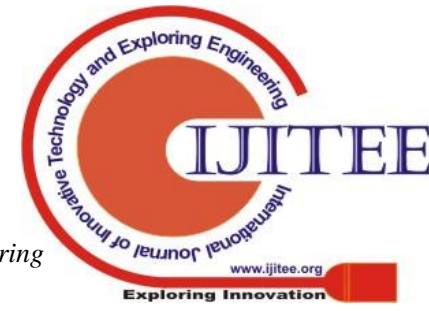




\section{Development of an electronic educational kit with android application that test student knowledge in series and parallel resistor for electrical circuit (Res-Circuit Quiz Board)}

Participants of the survey are inclusive of (20 respondents) from primary and secondary school students and remaining from the students Faculty Electrical Engineering Technology, University Teknikal Malaysia Melaka. The demographic of the respondentscan be seen from the pie chart inFig. 14. The survey carried out for primary and secondary school students who in physic or science field and the students from university with background of engineering. The procedure of data collection as follows: 1) The kit has been demonstrated to each of the respondents, individually. 2) Respondents also had an opportunity to try the kit for at least 10 minutes. Then the respondent is asked to fill up the survey consists of 16 questions. An interview is done for the respondents that is less than 13 years old.

Bar chart in Fig.15summarizes the result obtained from the survey. From the graph below we can conclude that most of the respondents agree with this project. For all questions, more than $70 \%$ of the respondents choose agreed that the question statement. This proves that the educational kit improves the student: hands-on skill (Q10), understanding (Q11-14), and motivation (Q15-17).
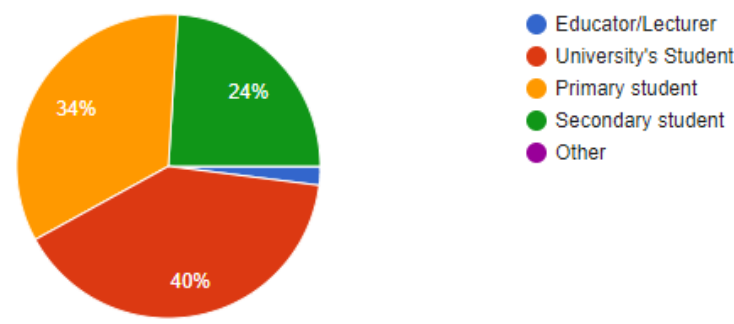

Fig. 14: Respondent's designation

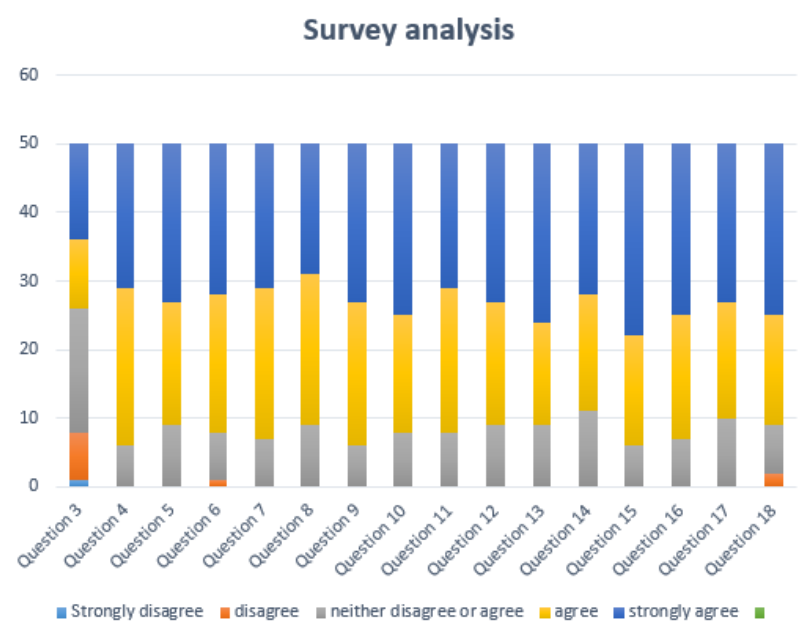

Fig. 15: Bar chart for the survey

\section{CONCLUSION}

This paper presented the development of an electronic educational quiz Board that test student knowledge on series and parallel resistor connection using Android application as graphical user interface. Detail of the hardware and software had been explained. The proved of concept had been tested to the target users. This project has been meeting all objectives of the project which not only to create interactive educational quiz board that aid student learning but also developing a portable and low cost educational kit.
Table 2: List of Questions

\begin{tabular}{|c|c|}
\hline $\begin{array}{l}\text { Question } \\
\text { No. }\end{array}$ & Survey Question \\
\hline 3 & Electrical Circuit is an interesting subject \\
\hline 4 & Educational Kit is related to the topic \\
\hline 5 & Educational kit in correct sequence \\
\hline 6 & Educational kit are according to student's level \\
\hline 7 & $\begin{array}{l}\text { Teacher/demonstrator are expert to use } \\
\text { educational kit }\end{array}$ \\
\hline 8 & Educational kit save student's time \\
\hline 9 & $\begin{array}{l}\text { Educational kit can be a highly interactive } \\
\text { during class session }\end{array}$ \\
\hline 10 & $\begin{array}{l}\text { Educational kit can help student to improve } \\
\text { their hands-on skill }\end{array}$ \\
\hline 11 & $\begin{array}{l}\text { Educational kit provide difficult things in } \\
\text { simple way to understand }\end{array}$ \\
\hline 12 & $\begin{array}{l}\text { Teacher/demonstrator clear the concept of } \\
\text { student by using educational kit }\end{array}$ \\
\hline 13 & $\begin{array}{l}\text { This educational kit can help lecturer to teach } \\
\text { student about Electrical Circuit }\end{array}$ \\
\hline 14 & $\begin{array}{l}\text { Students can operate this educational kit } \\
\text { without the guidance of educator/ teacher }\end{array}$ \\
\hline 15 & $\begin{array}{l}\text { Teacher/demonstrator guide their students to } \\
\text { use properly educational }\end{array}$ \\
\hline 16 & $\begin{array}{l}\text { Educational kit motivate the students toward } \\
\text { learning }\end{array}$ \\
\hline 17 & $\begin{array}{l}\text { Educational kit play important role in student's } \\
\text { learning }\end{array}$ \\
\hline 18 & $\begin{array}{l}\text { Educational kit make student's knowledge } \\
\text { learning long lasting }\end{array}$ \\
\hline
\end{tabular}

\section{ACKNOWLEDGMENT}

The authors would like to thank Universiti Teknikal Malaysia Melaka for sponsoring this work under the grant no. GLUAR/CARVELLO/2017/FTK-CERIA/I00023.

\section{REFERENCES}

1. C. Babadogan, S. Olkun, "Curriculum development models and reform in Turkish primary school mathematics curriculum," International Journal for Mathematics Teaching and Learning, 2006, [Online]. Available: http://www.cimt.org.uk/journal/index.htm

2. M. Hosein, and L. Bigram, "An educational bluetooth quizzing application in android," International Journal of Wireless \& Mobile Networks, 2013, pp.69-78.

3. S. Somyürek, "An effective educational tool: construction kits for fun and meaningful learning,"International Journal of Technology and Design Education, 2014, pp.25-41.

4. T. Jaakkola, and S. Nurmi, "Fostering elementary school students' understanding of simple electricity by combining simulation and laboratory activities."Journal of Computer Assisted Learning, 2008, pp.271-283.

5. L. Liégeois, and E. Mullet, "High school students' understanding of resistance in simple series electric circuits". International Journal of Science Education, 2002, pp.551- 564.

6. R. F. Mustapa, A. F. Z. Abidin, A. A. N. M. Amin, A. H. M. Nordin, and M. N. Hidayat, "Engineering is Fun: Embedded CDIO Elements in Electrical and Electronic Engineering Final Year Project", Proceeding of the IEEE 9th International Conference on Engineering Education, 2017.

7. M. H. A. H. A. M. Faseh, F. N. Ismail, M. A. Majid, A. F. Z. Abidin, Z. M. Yusoff, R. Rifin, K. K.

Hasan, N. M. Ali, and Z. I.

Rizman, "E-PLC: The

Development

Programmable

of

Logic 
Controller Trainer that Translates Mnemonic Codes to Hardware Simulation", Journal of Fundamental and Applied Sciences, 2018, pp. 499-513.

8. A. Anuar, A. F. Hussin, M. A. Majid, A. F. Z. Abidin, Z. M. Yusoff, K K. Hassan, N. M. Ali, M. H. Harun, and Z. I. Rizman, "E-Tester: The Development of an Electronic Board that Check Commonly Used Arduino-Based Electronic Components and Modules", Journal of Fundamental Applied Science, 2018, pp. 514-523.

9. R. Rifin, T. E. Fang, A. F. Z. Abidin, A. Adam, M. A. Majid, and A Zainuddin, S. H. Mohammad, M.H. Harun, Z. I. Rizman, "Examwiz: A Development and Implementation of an Android Based Examination", Journal of Fundamental Applied Science, 2018, pp. 965-976.

10. M. F. Z. M. Zakaria, S. A. C. Aziz, A. F. Z. Abidin, M. A. Adip, N. Rahim, and W. H. W. Hassan, "The Development of an Electronic Educational Quiz Board that Test Student Knowledge on Control Principle's Second Order Transient Response by Using DC Motor Speed Control as Application", ARPN Journal of Engineering and Applied Sciences, 2018, pp.4079-4082.

11. M. R. Yaacob, A. I. M. Diah, A. F. Z. Abidin, K. A. Kadiran, R. F. Mustapa, M. Abdullah, M. I. Ismail, and S. N. A. H. Zaiton, "e-Flowchart: An Electronic Educational Quiz Board that Test Student Knowledge on C Programming Concept using Flowchart Command," ARPN Journal of Engineering and Applied Sciences, 2018, pp. 9081-9085.

12. M. I. Z. M. Zabidi, L. T. Yung, K. A. Kadiran, A. F. Z. Abidin, M. H. Harun, M. S. Karis, N. M. Ali, and Z. M. Yusoff, "e-Transform: High School Educational Kit for Learning Mathematical Transformation," Proceeding of Innovative Teaching and Learning Day 2018, 2018.

13. K. A. Kadiran, A. F. Z. Abidin, M. F. Ishak, M. F. Majidan, R. Rifin, Z M. Yusoff, M. I. Z. M. Zabidin, E. F. Azmi, and A. Samsudin, "E-Water Level: Educaational Kit for Learning Control System by Using Water Level Application," Proceeding of Innovative Teaching and Learning Day 2018, 2018.

14. A. F. Hafizan, A. F. Z. Abidin, N. Z. N. Suhaimi, M. M. Mustam, K. A. Kadiran, S. A. Saleh, and W. N. A. Rasid, "E-Congkak: The Development of an Electronic Congkak Board Game to Promote Traditional Board Game to Younger Malaysian Generation," ARPN Journal of Engineering and Applied Sciences, 2018, pp. 9624-9630.

15. M. A. Hairuddin, N. D. K. Anuar, Z. M. Yusoff, A. F. Z. Abidin, and M. T. Nooritawati, "Computer Assisted E-Laboratory using LabView and Internet-of-Things Platform as Teaching Aids in the Industrial Instrumentation Course," International Journal of Online Engineering, 2018, pp. 26-42.

16. I. A. Rozani, A. F. Z. Abidin, M. S. Karis, M. N. M. Nizam, A. H Azahar, M. H. Harun, Z. M. Yusoff, K. K. Hassan, and B. N. Shah, "E-Othello: The Development of an Electronic-Hardware version of Traditional Othello Board Game," ARPN Journal of Engineering and Applied Sciences, 2019.

17. M. A. Husaini, A. F. Z. Abidin, B. N. Shah, M. B. Abdullah, K. A Kadiran, A. K. Khalid, H. B. A. Kasim, D. C. Lat, R. Razali, and N. S A. Rahman, "Rabbit and Carrot Electronic Board Game: The Development of an Educational Kit that Test Student Knowledge in Flowchart Concept," ARPN Journal of Engineering and Applied Sciences, 2019

18. M. I. Z. M. Zabidi, L. T. Yung, A. F. Z. Abidin, K. A. Kadiran, M. Abdullah, M. H. Harun, and A. H. Azahar, "A Brief Review of Educational Kit Publications from Year 2002 to 2016.," ARPN Journal of Engineering and Applied Sciences, 2019.

19. S.V.E. Arellano, J.M.G.N. Caguicla, and L.A.P. Desuasido, "Sign language and speech translation wearable device with android application for special education schools in the Philippines,' International Journal of Innovative Technology and Exploring Engineering, 2018, pp. 1-6.

20. R. Kraleva, and V. Kralev, "An evaluation of the mobile apps for children with special education needs based on utility function metrics", International Journal on Advanced Science, Engineering and Information Technology, 2018, pp 2269-2277.

21. K.S. Chung, H.W. Byun, S. Kim, H.C. Yu, "Interactive digital textbook development methodology for higher education", International Journal on Advanced Science, Engineering and Information Technology, 2018 pp 1534-1539.

\section{AUTHORS PROFILE}

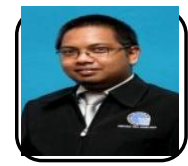

Mohd Firdaus (non-Member), Born in 1982. He is malaysian Researcher and Engineer. He graduated from Universiti Tenaga Nasional in Bachelor of Electrical Engineering. He finished Master Degree of EEIT at University of Applied Science Rosenheim, Germany. He worked in various multinational company such as Sony, Intel and Qimonda as Electrical Test Engineer. Currently he is a full-time researcher at Universiti Teknikal Malaysia Melaka, Fakulti Teknologi Kejuruteraan.His reseach mainly focus in Energy Efficiency, Renewable Energy and Electrical Vehicle.

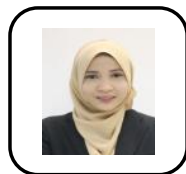

Nur Azmeen Iezzati Bt. Idrus was formerly an undergraduate student from Universiti Teknikal Malaysia Melaka with a Bachelor of Computer Engineering Technology (Computer System). Her research interests are microcontroller applications, control systems, digital system and electronic system design.

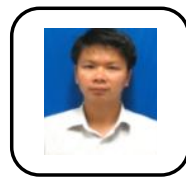

Amar Faiz Zainal Abidin, Faculty of Electrica Engineering Technology, Universiti Teknikal Malaysia Melaka, Melaka, Malaysia.

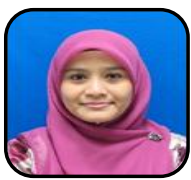

Siti Fatimah Sulaiman Sixthreceived B. Eng. (Industrial Electronics) from Universiti Teknikal Malaysia Melaka in 2009 and M. Eng. (Electrical Mechatronics and Automatic Control) from Universiti Teknologi Malaysia in 2012. She is currently pursuing $\mathrm{Ph} . \mathrm{D}$. degree in Electrical Engineering at Universiti Teknologi Malaysia. Her main research interest is in the field of control system design, system identification, mechatronics, automation, and instrumentation.

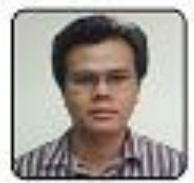

Rozi Rifin currently serves as a lecturer in electronics engineering at Universiti Teknologi MARA Cawangan Johor Kampus Pasir Gudang. He received B.Eng in Electronics from Universiti Sains Malaysia and M.Sc in Microelectronics from Nationa University of Malaysia. His research interests are in microelectronic fabrication, IC design, Internet of Thing, embedded system and Photovoltaic system. 